\title{
Reflections on the Educational Crisis and the Tasks of the Critical Scholar/ Activist
}

\author{
Michael W. Apple*, \\ Department of Curriculum and Instruction and Educational Policy Studies, University of \\ Wisconsin, Madison, WI, USA
}

\begin{abstract}
This is a time when education has become even more of a site of struggle. Dominant groups in a number of countries have attempted, often more than a little successfully, to limit criticism, to control access to research that documents the negative effects of their policies, and to deny the possibility of critically democratic alternatives. At the same time, critical perspectives have been built to challenge dominant understandings of education and the larger society. In this article, I want to do three things: 1) provide a general picture of the ideological situation we are facing; 2) publicly reflect on some of the critical perspectives in education that have grown in influence over the past years, since I have some worries about these perspectives if they are not more adequatelyand actively - connected to counter-hegemonic movements and struggles; and 3) suggest a set of actions that more adequately deal with the responsibilities of critical educators in a time of crisis and of the growing influences of conservative modernization. In order to do this, I will also need to ground some of my points in a series of personal reflections.
\end{abstract}

Keywords: neoliberalism; globalization; postcolonialism; critical pedagogy; public intellectuals Received: March 2015; Accepted: March 2015; Published: April 2015

\section{Introduction $^{1}$}

I want to begin this article with a personal example of some recent international politics surrounding school reforms. Two years ago I spent a semester as a Visiting Professor at the University of Melbourne in Australia. During my time in Melbourne,

ॠCorrespondence to: Michael W. Apple, Department of Curriculum and Instruction, University of Wisconsin, Teacher Education Building, 225 North Mills Street, Madison, WI 53706,USA. Email: apple@education.wisc.edu

${ }^{1}$ A longer version of the arguments in this article appears in Apple (2013). Various accounts of the arguments contained in this paper have been given at TsingHua University and Beijing Normal University in China, the University of Manchester in England, and the University of Buenos Aires and the Federal University of Rosario in Argentina, as well as the Federal University of Rio Grande do Sul in Brazil. I would like to thank the various faculty, students, and members of activist groups at these universities for their many insightful comments. 
I was asked to give a lecture to school principals and teachers in which I was to critically reflect on the policies that were being proposed in education and on how we could make schools more responsive to communities there and elsewhere. After I was given the invitation, a number of members of the Victoria State Department of Education and Early Childhood Development (DEECD) came to hear me give a more academic address at the university on the politics and effects of neoliberal agendas in education. Within a few days of that university address, my invitation to speak to school leaders was cancelled. 'My services were no longer required'. What I had to say was 'too controversial'.

The context of this decision was the following. The neoliberal government of the state was intent on imposing such policies as performance pay for teachers and principals, increased support for private and religious schools, corporate models of management, anti-union policies, and similar kinds of things. The union of teachers and principals was deeply opposed to these policies, but the government was adamant in having them take effect and was not willing to bargain seriously over them. It had also made it clear that it was not at all pleased to have these issues discussed publicly.

Let us be honest. This is a very difficult time in education. Neoliberal and conservative policies have had major effects on schools, on administrators, on teachers, and on all school staff. As I point out in a number of recent books, under the influence of those with increasing power in education and in all too much of society what is public is supposedly bad and what is private is supposedly good. Budget cuts have been pushed forward; jobs have been cut; attacks on educators at all levels and on their autonomy and their organisations gain more visibility; corporate models of competition, accountability, and measurement have been imposed; continual insecurity has become the norm. The loss of respect for the professionalism of educators is striking. These are truly international tendencies, ones found in an entire range of countries (Apple, 2006, 2010, 2013; See also Ball, 2012; Lipman, 2004, 2011).

What happened over the ensuing month was important, since the government created even more problems than it thought it had solved. There was an immediate sense of outrage on the part of educators and progressive groups. The media publicized the act of censorship and published a number of interviews with me and others condemning the DEECD's actions. The news stories about the decision to cancel my lecture, and more importantly about the issues that it raised concerning the disrespect the government consistently showed to teachers and school administrators, went viral on Facebook, Twitter, and other forms of social media. Actions and movements around the issues emerged and grew.

In response, the Australian Education Union organized an even larger audience for what was called 'The Cancelled Lecture: Understanding and Challenging the Attacks on State Education'. It was held at exactly the same date and time as the original lecture that had been cancelled. The Union also broadcast the lecture to many schools within the state whose distance from Melbourne made it impossible for principals and teachers to attend. In a final act of resistance, many principals and 
teachers who were to have gone to the conference at which I was to originally speak left the DEECD's conference and instead came to the Union's headquarters to hear me. We collectively engaged in a detailed discussion of the politics of education and how to resist the 'reforms' that were being imposed on schools and other areas of social policy.

A number of things are clear in this example of the politics of policy at the ground level. Sometimes the decisions by powerful groups to 'manage consent' by presenting only the knowledge that they consider to be safe can lead to contradictory results. They can and do create spaces for interruption. And in this case, the organized actions of educational unions and progressive social movements played a large part in countering these decisions.

\section{Conservative modernization and the current crisis}

I have given a rather personal introduction to this article to remind us that this is a time when education has become even more of a site of struggle. It is time when we must decide how we are to engage with groups involved in dealing with all of this in critically democratic ways. Dominant groups not only in Australia have attempted, often more than a little successfully, to limit criticism, and to control access to research that documents the negative effects of their policies, and to deny the possibility of critically democratic alternatives. They have pressed forward with an agenda that is claimed to simply guarantee efficiency, effectiveness, and cost savings. For them, only these kinds of policies can deal with the crisis in education. Empirically, this is more than a little incorrect (see, e.g. Apple, 2006; Berliner \& Glass, 2014; Lipman, 2011; Lynch, Grummel, \& Devine, 2012; Ravitch, 2010).

One of the major reasons for the continuation of dominant discourse and policies is that the very nature of our commonsense about education is constantly being altered. This is largely the result of the power of particular groups who understand that if they can change the basic ways we think about our society and its institutions - and especially our place in these institutions - these groups can create a set of policies that will profoundly benefit them more than anyone else. Dominant groups have actively engaged in a vast social/pedagogic process, one in which what counts as a good school, good knowledge, good teaching, and good learning - indeed what counts as democracy itself - are being radically transformed.

Although I have critically analysed this in much greater detail in Educating the 'Right' Way (Apple, 2006), let me say more about this process here. In a large number of countries, a complex alliance and power bloc has been formed that has increasing influence in education and all things social. This power bloc is what I have called conservative modernization. As I show, this alliance combines various groups (Apple, 2006). But while there are clear tensions and conflicts within this alliance, in general its overall aims are in providing the educational conditions believed necessary both for increasing international competitiveness, profit, and discipline and for returning us to a romanticized past of the 'ideal' home, family, and school. 


\section{W. Apple}

This new power bloc has integrated education into a wider set of ideological commitments. The objectives in education are the same as those which guide its economic and social welfare goals. They include the dramatic expansion of that eloquent fiction, the free market; the drastic reduction of government responsibility for social needs; the reinforcement of intensely competitive structures of mobility both inside and outside the school; the lowering of people's expectations for economic security; the 'disciplining' of culture and the body; and the popularization of what is clearly a form of Social Darwinist thinking.

The seemingly contradictory discourse of competition, markets, and choice on the one hand and accountability, performance objectives, standards, national testing, and national curriculum on the other has created a situation in which it is hard to hear anything else. Even though these seem to embody different tendencies, as I have demonstrated they actually oddly reinforce each other and help cement conservative educational positions into our daily lives (Apple, 2006).

I have given this brief description of this new hegemonic bloc because I want to situate what I now have to say in current realities. As in the past, education is deeply connected to social movements, contradictions, conflicts, antagonisms, and complicated alliances. Understanding dominance and interrupting its various forms is a crucial part of our work.

Stressing the social and political in education is not new of course, either in Norway, Greece, England, the United States, or elsewhere. Many critical scholars have critically discussed this at great length internationally. Under current situations, this fact is easy for some of us to forget. However, while the act of criticism is important it is not sufficient. Let me say more about this issue and about what it means personally and collectively. In the process, I want to do two things: 1) to publicly reflect on some of the critical perspectives in education that have grown in influence over the past years. (As you will see, I have some worries about these perspectives if they are not more adequately - and actively - connected to counter-hegemonic movements and struggles.); and 2) suggest a set of actions that more adequately deal with the responsibilities of critical educators in a time of crisis and of the growing influences of conservative modernization. In order to do this, I once again need to ground some of my points in a series of personal reflections.

\section{Education, knowledge, and power}

Over the past four decades I and others have been dealing with a number of 'simple' questions. I personally have been deeply concerned about the relationship between culture and power, about the relationship among the economic, political, and cultural spheres (see Apple \& Weis, 1983), about the multiple and contradictory dynamics of power and social movements that make education such a site of conflict and struggle, and about what all this means for educational work. In essence, I have been trying to answer a question that was put so clearly in the early decades of the last century in the United States by radical educator George Counts (1932) when he asked 'Dare the School Build a New Social Order?' Indeed, the title of 
my newest book, Can Education Change Society? (Apple, 2013), speaks directly to this question. ${ }^{2}$

Counts was a person of his time and the ways he both asked and answered this question were a bit naïve. But the tradition of radically interrogating schools and other pedagogic sites, of asking who benefits from their dominant forms of curricula, teaching, evaluation, and policy, of arguing about what they might do differently, and of asking searching questions of what would have to change in order for this to happen - all of this is what has worked through me and a considerable number of other people. We stand on the shoulders of many others in the United States, Greece, Norway, and elsewhere who have taken such issues seriously; and in a time of neoliberal attacks with their ensuing loss of collective memory, I hope to have contributed to the recovery of the collective memory of this tradition and to pushing it further along conceptually, historically, empirically, and practically (see also Warmington, 2014). In the process, I have focused much of my attention on formal institutions of schooling and on social movements that influence them.

Of course, no author does this by herself or himself. This is a collective enterprise. And no one who takes these questions seriously can answer them fully or without contradictions or even wrong turns or mistakes. As a collective project, it is one in which we not only stand on the shoulders of those whose work we draw upon critically but also one in which thoughtful criticism of our work is essential to progress. Compelling arguments cannot be built unless they are subjected to the light of others' thoughtful analyses of the strengths and limits of our claims. Thus, I want to do some of that self-reflective analysis here. My arguments are meant to be just as powerful a reminder to me as they are to the reader. My focus will be on the limits and possibilities of some of the approaches to understanding curriculum and critical pedagogy that have been internationally influential over the past decades.

One of the guiding questions within the field of education is a deceptively simple one: What knowledge is of most worth? Over the past four decades, an extensive tradition has grown around a restatement of that question. Rather than 'What knowledge is of most worth?' the question has been reframed. It has become 'Whose knowledge is of most worth?' (Apple, 1996, 2004, 2012, 2014). There are dangers associated with such a move, of course, including impulses toward reductionism and essentialism. These dangers arise when we assume, as some people have, that there is always a oneto-one correspondence between any knowledge that is seen as 'legitimate' or 'official' and dominant groups' understanding of the world. This is too simplistic, since official knowledge is often the result of struggles and compromises and at times can represent crucial victories, not only defeats, by subaltern groups (Apple, 2014; Apple \& Buras, 2006; Teese, 2013). However, the transformation of the question has led to immense progress in our understanding of the cultural politics of education in general and of the relations among educational policies, curricula, teaching, evaluation, and

\footnotetext{
${ }^{2}$ Luis Armando Gandin plays a large part in Can Education Change Society? He is co-author of one of the most important chapters, a detailed analysis of the critically oriented reforms in Porto Alegre and of what we can learn from them.
} 


\section{W. Apple}

differential power. Indeed, some of the most significant work on the intimate connections between culture and power in general has come out of the area of the sociology of school knowledge, critical pedagogy, and critical educational studies in general.

At the same time as we have made conceptual, historical, and empirical gains associated with this move, there has been an accompanying internationalization of the issues involved. Thus, issues of the cultural assemblages associated with empire and previous and current imperial projects have become more visible. Hence, for example, there has been an increasing recognition that critical educational studies must turn to issues of the global, of the colonial imagination, and to postcolonial approaches in order to come to grips with the complex and at times contradictory synchronic and diachronic relations between knowledge and power, between the state and education, and between civil society and the political imaginary (Apple, 2010).

For example, under the influences of a variety of critical works on the history of literacy and on the politics of popular culture (Raymond Williams's work was crucial historically here. See Williams, 1977, 1961; See also Apple, 2004, 2012), as in a number of other fields it became ever clearer to those of us in education that the very notion of the canon of 'official knowledge' had much of its history in a conscious attempt to 'civilize' both the working class and the 'natives' of an expanding empire (Apple, 2014). The very idea of teaching the 'Other' was a significant change, of course. For many years in Europe and Latin America, for example, the fear of working class and 'peasant' literacy was very visible. This will be more than a little familiar to those with an interest in the history of the relationship among books, literacy, and popular movements. Books themselves, and one's ability to read them, have been inherently caught up in cultural politics.

Take the case of Voltaire, that leader of the Enlightenment who so wanted to become a member of the nobility. For him, the Enlightenment should begin with the 'grands'. Only when it had captured the hearts and minds of society's commanding heights could it concern itself with the masses below. But, for Voltaire and many of his followers, one caution should be taken very seriously. One should take care to prevent the masses from learning to read (Darnton, 1982, p. 130). In many nations, this of course was reinscribed in often murderous ways in the prohibitions against teaching enslaved peoples how to read (although there is new historical evidence that documents that many enslaved people who were brought to the Americas were Muslim and may already have been literate in Arabic).

Such changes in how education and literacy were thought about did not simply happen accidentally. They were (and are) the results of struggles over who has the right to be called a person, over what it means to be educated, over what counts as official or legitimate knowledge, and over who has the authority to speak to these issues (Apple, 2013, 2014; Darnton, 2014; Mills, 1997). And these struggles need to be thought about using a range of critical tools, among them analyses based on theories of the state, of globalization, of the postcolonial, and so much more. But none of this is or will be easy. In fact, our work may be filled with contradictions. Take for instance the 
recent (and largely justifiable) attention being given to issues of globalization and postcolonialism in critical education, to which I turn in my next section.

\section{Globalization, postcolonialism, and education}

Let me state some of my worries as well as the strengths of these perspectives. At the outset, let me say that I no longer have any idea what the words globalization and postcolonial mean. They have become sliding signifiers, concepts with such a multiplicity of meanings that their actual meaning in any given context can only be determined by their use. As Wittgenstein (1963), Austin (1975), and others reminded us, language can be employed to do an impressive array of things. It can be used to describe, illuminate, control, legitimate, mobilize, and many other things. The language of postcolonialism(s) (the plural is important), for example, has many uses. However, all too often it has become something of a 'ceremonial slogan', a word that is publicly offered so that the reader may recognize that the author is au courant in the latest linguistic forms. Its employment by an author here is largely part of the conversion strategies so well captured by Bourdieu in Distinction (1984) and Homo Academicus (1988). Linguistic and cultural capital are performed publicly to gain mobility within the social field of the academy. In my most cynical moments, I worry that this is at times all too dominant within the largely white academy.

But, of course, the postcolonial experience(s) (and again the plural is important) and the theories of globalization that have been dialectically related to them are also powerful ways of critically engaging with the politics of empire and with the ways in which culture, economy, and politics all interact globally and locally in complex and over-determined ways. Indeed, the very notions of postcolonialism and globalization 'can be thought of as a site of dialogic encounter that pushes us to examine center/ periphery relations and conditions with specificity, wherever we may find them' (Dimitriadis \& McCarthy, 2001, p. 10). When not used simply rhetorically, they are essential tools in our struggles against the global neoliberal and neoconservative agendas.

As they have influenced critical educational efforts, some of the core politics behind postcolonial positions are summarized well by Dimitriadis and McCarthy (2001) when they state that 'The work of the postcolonial imagination subverts extant power relations, questions authority, and destabilizes received traditions of identity' (p. 10; see also Bhabha, 1994 and Spivak, 1988).

Educators interested in globalization, in the neoliberal depredations I discussed earlier in this essay, and in postcolonial positions have largely taken them to mean the following. They imply a conscious process of repositioning, of 'turning the world upside down' (Young, 2003, p. 2). They mean that the world is seen relationally - as being made up of relations of dominance and subordination and of movements, cultures, and identities that seek to interrupt these relations. They also mean that if you are someone who has been excluded by the 'west's' dominant voices geographically, economically, politically, and/or culturally or you are inside the west but not really part of it, then 'postcolonialism offers you a way of seeing things differently, a language and a politics in which your interests come first, not last' (p. 2). 


\section{W. Apple}

Some of the best work in the field of education mirrors Robert Young's more general claim that postcolonialism and the global sensitivities that accompany it speak to a politics and a 'philosophy of activism' that involve contesting these disparities. It extends the anti-colonial struggles that have such a long history and asserts ways of acting that challenge 'western' ways of interpreting the world (p. 4). This is best stated by Young (2003) in the following two quotes:

Above all, postcolonialism seeks to intervene, to force its alternative knowledges into the power structures of the west as well as the non-west. It seeks to change the way people think, the way they behave, to produce a more just and equitable relation between different people of the world. (p. 7)

and

Postcolonialism ... is a general name for those insurgent knowledges that come from the subaltern, the dispossessed, and seek to change the terms under which we all live. (p. 20)

Of course, what Young says about postcolonialism is equally true about theories of globalization and about the entire tradition of critical educational scholarship and activism. Indeed, this is supposed to be one of the fundaments of the entire sphere of critical analyses and actions, especially those that constitute critical pedagogy as well. These reminders about insurgent knowledges however need to be connected relationally to something outside themselves. That connection to the 'outside' cannot be simply rhetorical.

\section{Knowledge from below}

If one of the most powerful insights of the literature in critical pedagogy and in the growing turn toward theories of globalization and postcolonial perspectives is the valorization of knowledge from below, is this sufficient? We know that the issue is not whether 'the subaltern speak', but whether they are listened to (Apple \& Buras, 2006; Spivak, 1988). Yet this too can be largely a rhetorical claim unless it gets its hands dirty with the material realities faced by all too many subaltern peoples.

A focus within the critical community(ies) on 'knowledge and voices from below' has at times bordered on what Whitty called 'romantic possibilitarianism' (Whitty, 1974). It is all so cultural that it runs the risk of evacuating the gritty materialities of daily lives and of economic relations. 'Gritty materialities' can too often get sacrificed on the altar of the relativistic assumptions of 'the world of discourses'. For all of the very evident power of postmodern and postcolonial cultural theories, critical analyses of political economy at times get forgotten.

Putting political economy back in requires effort. But let me make one suggestion of where to begin. With its brutally honest picture of what life is like for millions, even billions of people who live, attempt to exist, on the edge, Mike Davis' book, Planet of Slums (2006), demonstrates in no uncertain terms that without a serious recognition of ways in which the conjunctural specifics of the effects of global capital are transforming the landscape we sometimes too abstractly theorize about, we shall be unable to understand why people act in the ways they do in such situations. 
As he reminds us, words such as food, housing, work, and education should never be thought of as nouns. Instead, they are verbs. They require constant creative labor by the poor and dispossessed.

Work such as Davis goes a long way toward correcting the overemphasis on the discursive that so often plagues parts of postcolonial and critical pedagogical literature in education and elsewhere. And many of us need to be constantly reminded of the necessity to ground our work in a much more thorough understanding of the realities the oppressed face every day. Any work in education that is not grounded in these realities may turn out to be one more act of colonization, its rhetorical surface covering the fact that it is not organically connected to actual progressive social movements. I am very wary of over-stating my arguments here. Many of the readers of this essay are certainly deeply connected to counter-hegemonic movements around gender and sexuality, disability, 'race', immigrant rights, class relations, and so much more. But we are not immune to the pressures of overly academicizing the political rather than politicizing the academic.

\section{On being 'organic' and the tasks of the critical scholar/activist}

Do not misunderstand me. Used reflexively, the theories and perspectives I have discussed so far are of great significance. At the same time, however, it is important to remember that in the Americas and elsewhere the positions inspired by, say, postcolonialism and critical pedagogy are not actually especially new in education. Even before the impressive and influential work on critical pedagogy by the great Brazilian educator, Paulo Freire (Freire, 1970), subaltern groups had developed counter-hegemonic perspectives and an extensive set of ways of interrupting colonial dominance in education and in cultural struggles in general (see, e.g. Jules, 1991; Lewis, 1993, 2000; Livingston, 2003; Wong, 2002). But the fact that theories of globalization and postcolonialism are now becoming more popular in critical educational studies is partly due to the fact that the field itself in the US, throughout Latin America, Greece, and the Nordic nations, for example, has a very long tradition of engaging in analyses of hegemonic cultural form and content and in developing oppositional educational movements, policies, and practices (see. e.g. Aasen, 2003; Apple, 2004, 2006; Apple \& Buras, 2006).

Is documenting and recognizing this history enough? If not, how then do we extend this history of critical and counter-hegemonic work? How do we defend and ground ourselves in this history and still push forward in ways that respect the past efforts but still go beyond them when necessary? Given the power of conservative modernization in current educational policy and practice, what roles should we take on? Here I am reminded of the radical sociologist Michael Burawoy's arguments for a critical sociology. As he says, a critical sociology is always grounded in two key questions: 1) Sociology for whom? and 2) Sociology for what? (Burawoy, 2005). The first asks us to think about repositioning ourselves so that we see the world through the eyes of the dispossessed. The second asks us to connect our work to the complex issues surrounding a society's moral compass, its means and ends. 


\section{W. Apple}

For many people, their original impulses toward critical theoretical and political work in education were fueled by a passion for social justice, economic equality, human rights, sustainable environments, an education that is worthy of its namein short a better world. Yet, as I stated in the opening sections of this essay, this is increasingly difficult to maintain in the situation in which so many of us find ourselves. Ideologically and politically much has changed. The early years of the $21 \mathrm{st}$ century have brought us unfettered capitalism which fuels market tyrannies and massive inequalities on a truly global scale (Davis, 2006). 'Democracy' is resurgent at the same time, but it all too often becomes a thin veil for the interests of the globally and locally powerful and for disenfranchisement, mendacity, and national and international violence (Burawoy, 2005, p. 260). The rhetoric of freedom and equality may have intensified, but there is unassailable evidence that there is ever deepening exploitation, domination, and inequality and that earlier gains in education, economic security, civil rights, and more are either being washed away or are under severe threat. The religion of the market (and it does function like a religion, since as I noted earlier it does not seem to be amenable to empirical critiques) coupled with very different visions of what the state can and should do can be summarized in one word - neoliberalism (Burawoy, 2005), although we know that no one term can actually totally encompass the forms of dominance and subordination that have such long histories in so many regions of the world (see Apple, 2013, 2006).

At the same time, in a worry I noted earlier, in the social field of power called the academy - with its own hierarchies and disciplinary (and disciplining) techniques, the pursuit of academic credentials, bureaucratic and institutional rankings, tenure files, indeed the entire panoply of normalizing pressures surrounding institutions and careers - all of this seeks to ensure that we all think and act 'correctly'. Yet, the original impulse is never quite entirely vanquished (Burawoy, 2005). The spirit that animates critical work can never be totally subjected to rationalizing logics and processes. Try as the powerful might, it will not be extinguished. But are there contradictions in such critical work? Take the case of critical pedagogy. The sense of crucial importance of interrupting dominance certainly remains alive in a good deal of the work done under that name. But are the answers that have been given within this tradition sufficient? Are there dangers there as well?

Having said that work in critical pedagogy is significant - and having sincerely meant it - once again, I have some worries. For me, some of the literature on 'critical pedagogy' is a vexed one. Like the concept of postcolonialism, it too now suffers from a surfeit of meanings and risks becoming largely rhetorical. It can mean anything from being responsive to one's students on the one hand to powerfully reflexive forms of content and processes that radically challenge existing relations of exploitation and domination on the other. And just like some of the literature on postcolonialism, the best parts of the writings on critical pedagogy are crucial challenges to our accepted ways of doing education. 
But there are portions of the literature in critical pedagogy that may also represent elements of conversion strategies by new middle class actors who are seeking to carve out paths of mobility within the academy. The function of such (often disembodied) writing at times is to solve the personal crisis brought about by the 'contradictory class location' (Wright, 1985) of academics who wish to portray themselves as politically engaged; but almost all of their political engagement is textual. Thus, their theories are (if you will forgive the use of a masculinist word) needlessly impenetrable, and the very difficult questions surrounding life in real institutionsand of what we should actually teach, how we should teach it, and how it should be evaluated - are seen as forms of 'pollution', too pedestrian to deal with. This can degenerate into elitism, masquerading as radical theory. But especially during a time of severe crises, serious theory about curriculum and pedagogy needs to be done in relation to its object. Indeed, this is not only a political imperative but an epistemological one as well. The development of critical theoretical resources is best done when it is dialectically and intimately connected to actual movements and struggles (Apple, 2006; Apple, Au, \& Gandin, 2009; Apple, Ball, \& Gandin, 2010; Apple et al., 2003).

Once again, what Michael Burawoy has called 'organic public sociology' provides key elements of how we might think about ways of dealing with this here. In his words, but partly echoing Gramsci as well, in this view the critical sociologist:

... works in close connection with a visible, thick, active, local, and often counterpublic. [She or he works] with a labor movement, neighborhood association, communities of faith, immigrant rights groups, human rights organizations. Between the public sociologist and a public is a dialogue, a process of mutual education ... The project of such [organic] public sociologies is to make visible the invisible, to make the private public, to validate these organic connections as part of our sociological life. (Burawoy, 2005, p. 265)

This act of becoming (and this is a project, for one is never finished, always becoming) a critical scholar/activist is a complex one. Because of this, let me extend my earlier remarks about the role of critical research in education. My points here are tentative and certainly not exhaustive. But they are meant to begin a dialogue over just what it is that 'we' should do.

In general, there are nine tasks in which critical analysis (and the critical analyst) in education must engage (Apple, 2013, 2010).

1. It must 'bear witness to negativity'. ${ }^{3}$ That is, one of its primary functions is to illuminate the ways in which educational policy and practice are connected to

\footnotetext{
${ }^{3}$ I am aware that the idea of 'bearing witness' has religious connotations, ones that are powerful in many parts of the West, but may be seen as a form of religious imperialism in other religious traditions. I still prefer to use it because of its powerful resonances with ethical discourses. But I welcome suggestions from, say, Muslim, Jewish, and other critical educators and researchers for alternative concepts that can call forth similar responses. I want to thank Amy Stambach for this point.
} 
the relations of exploitation and domination - and to struggles against such relations - in the larger society. ${ }^{4}$

2. In engaging in such critical analyses, it also must point to contradictions and to spaces of possible action. Thus, its aim is to critically examine current realities with a conceptual/political framework that emphasizes the spaces in which more progressive and counter-hegemonic actions can, or do, go on. This is an absolutely crucial step, since otherwise our research can simply lead to cynicism or despair.

3. At times, this also requires a broadening of what counts as 'research'. Here I mean acting as critical 'secretaries' to those groups of people and social movements who are now engaged in challenging existing relations of unequal power or in what elsewhere has been called 'nonreformist reforms', a term that has a long history in critical sociology and critical educational studies (Apple, 2012). This is exactly the task that was taken on in the thick descriptions of critically democratic school practices in Democratic Schools (Apple \& Beane, 2007; see also Gutstein, 2006) and in the critically supportive descriptions of the transformative reforms such as the Citizen School and participatory budgeting in Porto Alegre, Brazil (see Apple, 2013; Apple et al., 2003; Gandin \& Apple, 2012; Wright, 2010). ${ }^{5}$ The same is true for CREA, an interdisciplinary research center at the University of Barcelona that is a model of how to build a research agenda and then create policies and programs that empower those who are economically and culturally marginalized in our societies (Alexiu \& Sorde, 2011; Aubert, 2011; Christou \& Puivert, 2011; Flecha, 2009, 2011; Gatt, Ojaja, \& Soler, 2011) and for The Centre for Equality Studies at University College, Dublin. It too has been at the center of research and action that stresses not only poverty and inequality, but movements towards equality in multiple relations of domination (Baker, Lynch, Cantillon, \& Walsh, 2004; Lynch, Baker, \& Lyons, 2009).

4. When Gramsci (1971) argued that one of the tasks of a truly counter-hegemonic education was not to throw out 'elite knowledge' but to reconstruct its form and content so that it served genuinely progressive social needs, he provided a key to another role 'organic' and 'public' intellectuals might play. Thus, we should not be engaged in a process of what might be called 'intellectual suicide'. That is, there are serious intellectual (and pedagogic) skills in dealing with the histories and debates surrounding the epistemological, political, and educational issues involved in justifying what counts as important knowledge and what counts as

\footnotetext{
${ }^{4}$ Here, exploitation and domination are technical not rhetorical terms. The first refers to economic relations, the structures of inequality, the control of labor, and the distribution of resources in a society. The latter refers to the processes of representation and respect and to the ways in which people have identities imposed on them. These are analytic categories, of course, and are ideal types. Most oppressive conditions are partly a combination of the two. These map on to what Fraser (1997) calls the politics of redistribution and the politics of recognition.

${ }^{5}$ Luis Armando Gandin's close connections to and analyses of the critically democratic policies and practices in education in Porto Alegre provide outstanding examples of such efforts. See also Wright (2010).
} 
an effective and socially just education. These are not simple and inconsequential issues and the practical and intellectual/political skills of dealing with them have been well developed. However, they can atrophy if they are not used. We can give back these skills by employing them to assist communities in thinking about this, learning from them, and engaging in the mutually pedagogic dialogues that enable decisions to be made in terms of both the short-term and long-term interests of dispossessed peoples (see Apple et al., 2003; Borg \& Mayo, 2007; Burawoy, 2005; Freire, 1970).

5. In the process, critical work has the task of keeping traditions of radical and progressive work alive. In the face of organized attacks on the 'collective memories' of difference and critical social movements, attacks that make it increasingly difficult to retain academic and social legitimacy for multiple critical approaches that have proven so valuable in countering dominant narratives and relations, it is absolutely crucial that these traditions be kept alive, renewed, and when necessary criticized for their conceptual, empirical, historical, and political silences or limitations. This involves being cautious of reductionism and essentialism and asks us to pay attention to what Fraser has called both the politics of redistribution and the politics of recognition (Fraser, 1997; see also Apple, 2013 and Anyon et al., 2009). This includes not only keeping theoretical, empirical, historical, and political traditions alive but, very importantly, extending and (supportively) criticizing them. And it also involves keeping alive the dreams, utopian visions, and 'non-reformist reforms' that are so much a part of these radical traditions (Apple, 2012; Apple et al., 2003; Apple, 2010; Jacoby, 2005; Teitelbaum, 1993).

6. Keeping such traditions alive and also supportively criticizing them when they are not adequate to deal with current realities cannot be done unless we ask 'For whom are we keeping them alive?' and 'How and in what form are they to be made available?' All of the things I have mentioned above in this taxonomy of tasks require the relearning or development and use of varied or new skills of working at many levels with multiple groups. Thus, journalistic and media skills, academic and popular skills, and the ability to speak to very different audiences are increasingly crucial (Apple, 2006; Boler, 2008). This requires us to learn how to speak in different registers and to say important things in ways that do not require that the audience or reader do all of the work.

7. Critical educators must also act in concert with the progressive social movements their work supports or in movements against the rightist assumptions and policies they critically analyze. This is another reason that scholarship in critical education implies becoming an 'organic' or 'public' intellectual. One must participate in and give one's expertise to movements surrounding actions to transform both a politics of redistribution and a politics of recognition. It also implies learning from these social movements (Anyon, 2014). This means that the role of the 'unattached intelligentsia' (Mannheim, 1936), someone who 'lives on the balcony' (Bakhtin, 1968), is not an appropriate model. As Bourdieu (2003, p. 11) reminds us, for example, our intellectual efforts are crucial, but 
they 'cannot stand aside, neutral and indifferent, from the struggles in which the future of the world is at stake'.

8. Building on the points made in the previous paragraph, the critical scholar/ activist has another role to play. She or he needs to act as a deeply committed mentor, as someone who demonstrates through her or his life what it means to be both an excellent researcher and a committed member of a society that is scarred by persistent inequalities. She or he needs to show how one can blend these two roles together in ways that may be tense, but still embody the dual commitments to exceptional and socially committed research and participating in movements whose aim is interrupting dominance. It should be obvious that this must be fully integrated into one's teaching as well.

9. Finally, participation also means using the privilege one has as a scholar/activist. That is, each of us needs to make use of one's privilege to open the spaces at universities and elsewhere for those who are not there, for those who do not now have a voice in that space and in the 'professional' sites to which, being in a privileged position, you have access. This can be seen, for example, in the history of the 'activist-in-residence' program at the University of Wisconsin Havens Center for Social Justice, where committed activists in various areas (the environment, indigenous rights, housing, labor, racial disparities, education, and so on) were brought in to teach and to connect our academic work with organized action against dominant relations. Or it can be seen in a number of Women's Studies programs and Indigenous, Aboriginal, and First Nation Studies programs that historically have involved activists in these communities as active participants in the governance and educational programs of these areas at universities.

\section{Conclusion}

I have used this article to present some personal and intellectual reflections on a number of important tendencies and tensions in critical education and its response to the educational crisis that so many nations are currently experiencing. In response to this, I've also laid out nine tasks as a beginning list of things that the scholar activist as a public intellectual needs to do. These tasks are demanding and no one person can engage equally well in all of them simultaneously. What we can do is honestly continue our attempt to come to grips with the complex intellectual, personal, and political tensions and activities that respond to the demands of this role. Actually, although at times problematic, 'identity' may be a more useful concept here. It is a better way to conceptualize the interplay among these tensions and positions, since it speaks to the possible multiple positionings one may have and the contradictory ideological forms that may be at work both within oneself and in any specific context (see Youdell, 2011). And this requires a searching critical examination of one's own structural location, one's own overt and tacit political commitments, and one's own embodied actions once this recognition in all its complexities and contradictions is taken as seriously as it deserves. 
This speaks to the larger issues about the politics of knowledge and people of which I spoke earlier and to which for example postcolonial authors such as Young (2003), Bhabha (1994), Spivak (1988), and others have pointed. Concepts such as 'critical pedagogy', 'hybridity', 'marginalization', 'subaltern', 'cultural politics', 'globalization', 'postcolonial', and the entire panoply of critical educational and pedagogic vocabulary can be used in multiple ways. They are meant to signify an intense set of complex and contradictory historical, geographic, economic, and cultural relations, experiences, and realities. But given the social, ideological, and political context in which education exists currently, what must not be lost in the process of using them is the inherently political nature of their own history and interests.

Used well, there is no 'safe' or 'neutral' way of mobilizing them - and rightly so. They are meant to be radically counter-hegemonic and they are meant to challenge even how we think about and participate in counter-hegemonic movements. How can we understand this, if we do not participate in such movements ourselves? Paulo Freire certainly did. So did E. P. Thompson, C. L. R. James, W. E. B. DuBois, Carter Woodson, Angela Davis, bell hooks, and so many others. The list gets even longer when we include, as we must, the people and movements that have played and continue to play such a large part in the continuing struggle to build an education that is truly critically democratic in nations and 'nation to be' throughout the world including Norway, the United States, and elsewhere. Can we do less?

As my introductory section on the attempts to silence me demonstrates, dominant groups will not stand idly by when we individually and collectively act to speak back. But as that example also shows, they cannot totally control the terrain on which such acts occur. Nor can they totally control its outcome. Spaces for counter-hegemonic work are constantly being created at the very same moment as dominant groups seek to close other spaces. Recognizing and filling these spaces is as crucial as it has even been.

\section{Biography}

Michael W. Apple is John Bascom Professor of Curriculum and Instruction and Educational Policy Studies at the University of Wisconsin, Madison. Among his recent books are: Can Education Change Society? (2013); Knowledge, Power, and Education (2013); and Official Knowledge, 3rd edition (2014).

\section{References}

Aasen, P. (2003). What happened to social-democratic progressivism in Scandinavia? In M. W. Apple, et al. (Eds.), The state and the politics of knowledge (pp. 109-148). New York, NY: RoutledgeFalmer.

Alexiu, T. M., \& Sorde, T. (2011). How to turn difficulties into opportunities: Drawing from diversity to promote social cohesion. International Studies in Sociology of Education, 21, 49-62.

Anyon, J. (2014). Radical possibilities (2nd ed.). New York, NY: Routledge.

Anyon, J., Dumas, M., Linville, D., Nolan, K., Perez, M., Tuck, E., \& Weiss, J. (2009). Theory and educational research. New York, NY: Routledge.

Apple, M. W. (1996). Cultural politics and education. New York, NY: Teachers College Press.

Apple, M. W. (2004). Ideology and curriculum (3rd ed.). New York, NY: Routledge.

Apple, M. W. (2006). Educating the "right" way: Markets, standards, god, and inequality (2nd ed.). New York, NY: Routledge.

Apple, M. W. (Ed.). (2010). Global crises, social justice, and education. New York, NY: Routledge. 
Apple, M. W. (2012). Education and power (revised Routledge Classic edition). New York, NY: Routledge.

Apple, M. W. (2013). Can education change society? New York, NY: Routledge.

Apple, M. W. (2014). Official knowledge (3rd ed.). New York: Routledge.

Apple, M. W., Au, W., \& Gandin, L. A. (Eds.). (2009). The Routledge international handbook of critical education. New York, NY: Routledge.

Apple, M. W., Ball, S., \& Gandin, L. A. (Eds.). (2010). The Routledge international handbook of the sociology of education. New York, NY: Routledge.

Apple, M. W., \& Beane, J. A. (Eds.). (2007). Democratic schools: Lessons in powerful education. Portsmouth, NH: Heinemann.

Apple, M. W., \& Buras, K. L. (Eds.). (2006). The subaltern speak: Curriculum, power, and educational struggles. New York, NY: Routledge.

Apple, M. W., \& Weis, L. (Eds.). (1983). Ideology and practice in schooling. Philadelphia, PA: Temple University Press.

Apple, M. W., Aasen, P., Cho, M. S., Gandin, L. A., Oliver, A., Sung, Y. K., .. Wong, T. H. (2003). The state and the politics of knowledge. New York, NY: Routledge.

Aubert, A. (2011). Moving beyond social inclusion through dialogue. International Studies in Sociology of Education, 21, 63-75.

Austin, J. L. (1975). How to do things with words. Cambridge, MA: Harvard University Press.

Baker, J., Lynch, K., Cantillon, S., \& Walsh, S. (2004). Equality: From theory to action. New York, NY: Palgrave Macmillan.

Bakhtin, M. M. (1968). Rabelais and his world. (H. Iswolsky, Trans.). Cambridge, MA: MIT Press.

Bhabha, H. (1994). The location of culture. New York, NY: Routledge.

Ball, S. (2012). Global education inc. New York, NY: Routledge.

Berliner, D., \& Glass, G. (2014). 50 myths and lies that threaten America's public schools. New York, NY: Teachers College Press.

Boler, M. (Ed.). (2008). Digital media and democracy: Tactics in hard times. Cambridge, MA: MIT Press.

Borg, C., \& Mayo, P. (2007). Public intellectuals: Radical democracy and social movements. New York, NY: Peter Lang.

Bourdieu, P. (1984). Distinction. Cambridge, MA: Harvard University Press.

Bourdieu, P. (1988). Homo academicus. Stanford, CA: Stanford University Press.

Bourdieu, P. (2003). Firing back: Against the tyranny of the market 2. New York, NY: New Press.

Burawoy, M. (2005). For public sociology. British fournal of Sociology, 56, 259-294.

Christou, M., \& Puigvert, L. (2011). The role of "other women" in current educational transformations. International Studies in Sociology of Education, 21, 77-90.

Counts, G. (1932). Dare the school build a new social order? New York, NY: The John Day Company.

Darnton, R. (1982). The literary underground of the old regime. Cambridge, MA: Harvard University Press.

Darnton, R. (2014). Censors at work: How states shaped literature. New York, NY: Norton.

Davis, M. (2006). Planet of slums. New York, NY: Verso.

Dimitriadis, G., \& McCarthy, C. (2001). Reading and teaching the postcolonial. New York, NY: Teachers College Press.

Flecha, R. (2009). The educative city and critical education. In M. W. Apple, W. Au, \& L. A. Gandin (Eds.), The Routledge international handbook of critical education (pp. 327-340). New York, NY: Routledge.

Flecha, R. (2011). The dialogic sociology of education. International Studies in Sociology of Education, 21, 7-20.

Fraser, N. (1997). Fustice interruptus. New York, NY: Routledge.

Freire, P. (1970). Pedagogy of the oppressed. New York, NY: Herder and Herder.

Gandin, L. A., \& Apple, M. W. (2012). Can critical democracy last: Porto Alegre and the struggle over 'thick' democracy in education. Fournal of Education Policy, 27, 621-639.

Gatt, S., Ojala, M., \& Soler, M. (2011). Promoting social inclusion counting with everyone: Learning communities and INCLUDE-ED. International Studies in Sociology of Education, 21, 33-47.

Gramsci, A. (1971). Selections from the prison notebooks. (Q. Hoare \& G. N. Smith, Trans.). New York, NY: International Publishers.

Gutstein, E. (2006). Reading and writing the world with mathematics. New York, NY: Routledge.

Jacoby, R. (2005). Picture imperfect: Utopian thought for an anti-utopian age. New York, NY: Columbia University Press.

Jules, D. (1991). Building democracy. In M. W. Apple \& L. Christian-Smith (Eds.), The politics of the textbook (pp. 259-287). New York, NY: Routledge. 


\section{Reflections on the Educational Crisis}

Lewis, D. L. (1993). W. E. B. DuBois: Biography of a race, 1868-1919. New York, NY: Henry Holt.

Lewis, D. L. (2000). W. E. B. DuBois: The fight for equality and the American century. New York, NY: Henry Holt.

Lipman, P. (2004). High stakes education. New York, NY: Routledge.

Lipman, P. (2011). The new political economy of education. New York, NY: Routledge.

Livingston, G. (2003). Chronic silencing and struggling without witness: Race, education and the production of political knowledge (Unpublished $\mathrm{PhD}$ dissertation). University of Wisconsin, Madison.

Lynch, K., Baker, J., \& Lyons, M. (2009). Affective equality: Love, care, and injustice. New York, NY: Palgrave Macmillan.

Lynch, K., Grummell, B., \& Devine, D. (2012). New managerialism in education. New York, NY: Palgrave Macmillan.

Mills, C. (1997). The racial contract. Ithaca, NY: Cornell University Press.

Mannheim, K. (1936). Ideology and utopia. New York, NY: Harvest Books.

Ravitch, D. (2010). The death and life of the great American school system. New York, NY: Basic Books.

Spivak, G. (1988). Can the subaltern speak? In C. Nelson \& L. Grossberg (Eds.), Marxism and the interpretation of culture (pp. 271-313). Urbana, IL: University of Illinois Press.

Teese, R. (2013). Academic success and social power (2nd ed.). Melbourne: Australian Scholarly Publishing.

Teitelbaum, K. (1993). Schooling for good rebels. Philadelphia, PA: Temple University Press.

Warmington, P. (2014). Black British intellectuals and education. New York, NY: Routledge.

Whitty, G. (1974). Sociology and the problem of radical educational change. In M. Flude \& J. Ahier (Eds.), Educability, schools, and ideology (pp. 112-137). London: Halstead Press.

Williams, R. (1961). The long revolution. London: Chatto and Windus.

Williams, R. (1977). Marxism and literature. New York, NY: Oxford University Press.

Wittgenstein, L. (1963). Philosophical investigations. Oxford: Blackwell.

Wong, T. H. (2002). Hegemonies compared. New York, NY: Routledge.

Wright, E. O. (1985). Classes. New York, NY: Verso.

Wright, E. O. (2010). Envisioning real utopias. New York, NY: Verso.

Young, R. (2003). Postcolonialism. New York, NY: Oxford University Press.

Youdell, D. (2011). School trouble: Identity, power and politics in education. London: Routledge. 